CLINICAL STUDY

\title{
GH response to ghrelin in subjects with congenital GH deficiency: evidence that ghrelin action requires hypothalamic-pituitary connections
}

\author{
Mohamad Maghnie, Maria Cristina Pennati ${ }^{1}$, Elisa Civardi ${ }^{1}$, Natascia Di Iorgi, Gianluca Aimaretti ${ }^{2}$, Maria $^{3}$ \\ Loreta Foschini $^{3}$, Ginevra Corneli ${ }^{2}$, Carmine Tinelli ${ }^{4}$, Ezio Ghigo ${ }^{5}$, Renata Lorini and Sandro Loche ${ }^{3}$ \\ Department of Paediatrics, IRCCS Giannina Gaslini, University of Genova, Largo Gerolamo Gaslini, 5, 16147 Genova, Italy, ${ }^{1}$ Department of Paediatrics, \\ University of Pavia, Pavia, Italy, ${ }^{2}$ Endocrinology, Department of Clinical and Experimental Medicine, University of Piemonte Orientale, Novara, Italy, \\ ${ }^{3}$ Servizio di Endocrinologia Pediatrica Ospedale Regionale per le Microcitemie, Cagliari, Italy, ${ }^{4}$ Division of Biometry-Scientific Direction, IRCCS Policlinico \\ San Matteo, Pavia, Italy and ${ }^{5}$ Division of Endocrinology and Metabolic Diseases, University of Turin, Turin, Italy
}

(Correspondence should be addressed to M Maghnie; Email: mohamadmaghnie@ospedale-gaslini.ge.it)

\begin{abstract}
Objectives: Evaluation of GH response to ghrelin in patients with GH deficiency (GHD) may help to elucidate the site and mechanism of action of ghrelin. We aimed to investigate the GH-releasing effect of ghrelin in children and young adults with childhood-onset GHD.

Design: All subjects underwent ghrelin testing and neuro-imaging examination. Magnetic resonance imaging evidenced the presence of a vascular pituitary stalk (VPS) or its complete absence (PSA). Patients and methods: Seventeen prepubertal children and nine adult patients with childhood-onset GHD were selected for the study. The children were enrolled at a median age of 5.8 years. The adult subjects were included at a median age of 23.3 years. The diagnosis of GHD in the adult patients had been established at a median age of 8.5 years. Ghrelin was administered at a dose of $1 \mu \mathrm{g} / \mathrm{kg}$ body weight, i.v. at time zero, and blood for GH determination was obtained at $0,15,30,45,60,75,90$, 105 and $120 \mathrm{~min}$.

Results: Median GH response after ghrelin was similar between children and adults. Median peak GH response to ghrelin $(7.45 \mu \mathrm{g} / \mathrm{l}$, IQR: $3.9-11.3 \mu \mathrm{g} / \mathrm{l})$ was significantly higher in patients with VPS $(10.9 \mu \mathrm{g} / \mathrm{l}$, IQR: $2.4-15.1 \mu \mathrm{g} / \mathrm{l})$ than in those with PSA (IQR: 2.3-6.7 $\mu \mathrm{g} / \mathrm{l} ; P=0.001$ ). It was significantly higher in subjects with isolated GHD $(12.5 \mu \mathrm{g} / \mathrm{l}$, IQR: $10.8-15.5 \mu \mathrm{g} / \mathrm{l})$ than in those with multiple pituitary hormone deficiencies $(5.15 \mu \mathrm{g} / \mathrm{l}$, IQR: $2.4-9.0 \mu \mathrm{g} / \mathrm{l} ; P=0.003)$. No correlation was found between the $\mathrm{GH}$ peak after ghrelin and body mass index.

Conclusion: The GH response to ghrelin in patients with congenital hypopituitarism depends on the degree of the anatomical abnormalities and lends further support to the assumption that the main action of the peptide is exerted at the hypothalamic level and requires the integrity of hypothalamicpituitary connections.
\end{abstract}

European Journal of Endocrinology 156 449-454

\section{Introduction}

Growth hormone $(\mathrm{GH})$ secretion is regulated by the coordinated action of GH-releasing hormone (GHRH) and somatostatin (SRIH), which respectively stimulate and inhibit its release from the pituitary gland. The hypothalamic release of GHRH and SRIH is, in turn, under the regulation of a complex network of brain neurotransmitters and neuropeptides (1). GH secretion is also under the influence of metabolic and hormonal signals from the periphery (including glucocorticoids, thyroid hormones and sex steroids) which may modulate somatotrope function either directly or via the hypothalamus. Furthermore, GH regulates its own secretion by a feedback mechanism either by a direct action or mediated by the insulin-like growth factors
(IGFs) and possibly by other metabolic factors, such as free fatty acids, insulin and glucose (1).

Another GH regulatory system has been explained from the observation that small synthetic molecules called GH secretagogs (GHSs) have a strong GH-releasing activity by acting on the GHS receptor (GHS-R; for review, see (2)). The endogenous ligand of the GHS-R has recently been identified from the rat and human stomach and named ghrelin (3). Ghrelin and its synthetic analogs stimulate $\mathrm{GH}$ secretion in animals and humans in a dosedependent manner and act synergistically with GHRH (4-6). A number of studies have documented that the hypothalamus is their main site of action, and their mechanism(s) likely involve endogenous GHRH release as well as functional SRIH antagonistic activity (2). Although an exact physiological role for the ghrelin 
and the GHS-R in the regulation of GH secretion and growth has not yet been clearly established, a recent report has shown a loss of constitutive activity of the GHS-R in subjects with familial short stature (7). This might indicate that the role of the ghrelin system is crucial for maintaining normal GH secretion and hence normal growth.

We and other researchers have previously shown that the GH response to natural or synthetic GHS is reduced or absent in patients with hypothalamic-pituitary disconnection (8-10). In another study, we confirmed that the integrity of hypothalamic-pituitary connections is essential for GHS to express its full GH-releasing activity, and we showed that synthetic GHSs are able to stimulate GH secretion in patients with GHD who have a residual vascular component of the pituitary stalk (11). Likewise, the GH-releasing activity of the combined administration of GHRH plus arginine, reportedly recognized as a valuable diagnostic test in the diagnosis of GHD in adults and children, requires the integrity of hypothalamic-pituitary connections (12-14). In order to gain further insight into the site and mechanism of ghrelin action, we evaluated the GH response to ghrelin in a group of subjects with GHD due to congenital anomalies in hypothalamic-pituitary connections.

\section{Subjects and methods}

Seventeen prepubertal children and nine adult patients with childhood-onset GHD were selected for the study. Their main characteristics are summarized in Tables 1 and 2 . The children ( 12 boys and 5 girls) were enrolled at the time of GHD diagnosis at a median age of 5.8 years (range 3.50-12.4 years). The adult subjects (five males and four females) were included in the study at the time of re-evaluation of GH status, at a median age of 23.3 years (range 16.7-25.4 years) after adult height achievement and within 6 months after GH withdrawal. The diagnosis of GHD in these latter patients had been established at a median age of 8.5 years (range 2.3-16.2 years).

The diagnosis of GHD during childhood was based on clinical grounds and a GH response of $<10 \mu \mathrm{g} / \mathrm{l}$ to at least two stimulation tests (insulin-induced hypoglycemia $(0.1 \mathrm{U} / \mathrm{kg}$ body weight, regular insulin i.v.), arginine, glucagon, L-dopa). In the adult patients, GH treatment had been discontinued when growth velocity during the preceding year had dropped to $<1 \mathrm{~cm}$. GH secretion was re-evaluated by means of an insulin tolerance test (ITT; $0.1 \mathrm{U} / \mathrm{kg}$ body weight, regular insulin i.v.) performed between 0800 and $0900 \mathrm{~h}$ following overnight fasting. A GH response to $>5 \mu \mathrm{g} / \mathrm{l}$ was considered normal in young adults (15).

Pituitary-thyroid function was evaluated by measuring serum $\mathrm{FT}_{4}, \mathrm{FT}_{3}$, and thyroid-stimulating hormone (TSH). Hypothyroidism was defined as low or low-normal serum TSH concentration and low serum $\mathrm{FT}_{4}$ and $\mathrm{FT}_{3}$ concentrations. Plasma adrenocorticotropic hormone (ACTH) and serum cortisol values were measured in all patients in the morning at presentation. ACTH deficiency was defined as either a morning serum cortisol concentration of $<3.6 \mu \mathrm{g} / \mathrm{dl}(100 \mathrm{nmol} / \mathrm{l})$ or a cortisol serum concentration $<20 \mu \mathrm{g} / \mathrm{dl}(550 \mathrm{nmol} / \mathrm{l})$ during ITT. Serum follicle-stimulating hormone (FSH) and luteinizing hormone (LH) were measured at baseline and after the i.v. administration of $100 \mu \mathrm{g}$ gonadotropinreleasing hormone $(\mathrm{GnRH})$ in patients with suspected

Table 1 Clinical and growth hormone $(\mathrm{GH})$ response to ghrelin compared with standard pharmacological tests in children with structural hypothalamic-pituitary abnormalities.

\begin{tabular}{|c|c|c|c|c|c|c|c|c|}
\hline \multirow{2}{*}{$\begin{array}{l}\text { Case } \\
\text { no./sex }\end{array}$} & \multirow[b]{2}{*}{ Age } & \multirow[b]{2}{*}{ Ht (SDS) } & \multirow{2}{*}{$\begin{array}{c}\text { BMI } \\
\left(\mathrm{kg} / \mathrm{m}^{2}\right)\end{array}$} & \multicolumn{3}{|c|}{ GH Peak $(\mu \mathrm{g} / \mathrm{l})$} & \multirow[b]{2}{*}{ Associated hormone deficiencies } & \multirow{2}{*}{$\begin{array}{c}\text { MRI } \\
\text { findings }\end{array}$} \\
\hline & & & & $\operatorname{Arg}$ & Ins/other ${ }^{a}$ & Ghrelin & & \\
\hline $1 / \mathrm{M}$ & 3.5 & 3.3 & 17.2 & 1.1 & 1.7 & 17.5 & $\mathrm{GH}$ & VPS \\
\hline $2 / \mathrm{F}$ & 3.5 & -3.0 & 17.8 & 4.8 & 3.6 & 6.7 & $\mathrm{GH}+\mathrm{TSH}$ & PSA \\
\hline 3/M & 3.7 & -3.2 & 16.3 & 1.8 & 1.4 & 2.3 & $\mathrm{GH}+\mathrm{TSH}+\mathrm{ACTH}$ & PSA \\
\hline 4/M & 3.7 & -1.6 & 18.4 & 1.8 & 2.9 & 10.7 & $\mathrm{GH}$ & VPS \\
\hline $5 / \mathrm{M}$ & 3.8 & -3.1 & 15.7 & 0.5 & 0.9 & 3.9 & $\mathrm{GH}+\mathrm{TSH}+\mathrm{ACTH}$ & PSA \\
\hline $6 / \mathrm{M}$ & 4.2 & -3.9 & 16.7 & 2.7 & 4.5 & 7.3 & $\mathrm{GH}+\mathrm{TSH}$ & PSA \\
\hline 7/F & 4.7 & -2.6 & 16.9 & 1.4 & 2.1 & 5.1 & $\mathrm{GH}+\mathrm{TSH}$ & PSA \\
\hline $8 / F$ & 5.3 & -2.6 & 19.3 & 1.8 & 3.9 & 7.6 & $\mathrm{GH}+\mathrm{TSH}+\mathrm{LH}+\mathrm{FSH}+\mathrm{ACTH}$ & PSA \\
\hline 9/M & 5.8 & -2.8 & 17.9 & 3.6 & 5.7 & 16.5 & $\mathrm{GH}$ & VPS \\
\hline 10/M & 6.1 & -3.4 & 18.6 & 1.2 & 3.3 & 4.3 & $\mathrm{GH}+\mathrm{TSH}+\mathrm{ACTH}$ & PSA \\
\hline $11 / \mathrm{F}$ & 6.2 & -2.9 & 17.8 & 0.9 & 3.9 & 11.3 & $\mathrm{GH}$ & VPS \\
\hline $12 / \mathrm{M}$ & 6.8 & -2.1 & 19.4 & 2.8 & 6.9 & 14.6 & $\mathrm{GH}$ & VPS \\
\hline 13/M & 8.6 & -2.4 & 20.4 & 1.4 & 2.3 & 5.2 & $\mathrm{GH}+\mathrm{TSH}+\mathrm{LH}+\mathrm{FSH}+\mathrm{ACTH}$ & PSA \\
\hline $14 / \mathrm{M}$ & 8.7 & -3.8 & 20.9 & 3.4 & 1.2 & 10.9 & $\mathrm{GH}$ & VPS \\
\hline $15 / \mathrm{M}$ & 8.8 & -2.7 & 19.8 & 2.1 & 1.5 & 9.2 & $\mathrm{GH}+\mathrm{TSH}$ & VPS \\
\hline $16 / F$ & 9.3 & -4.7 & 21.2 & 0.8 & 1.9 & 3.2 & $\mathrm{GH}+\mathrm{TSH}+\mathrm{ACTH}$ & PSA \\
\hline $17 / \mathrm{M}$ & 12.4 & -3.3 & 22.4 & 0.9 & 2.6 & 9.0 & $\mathrm{GH}+\mathrm{TSH}$ & VPS \\
\hline
\end{tabular}

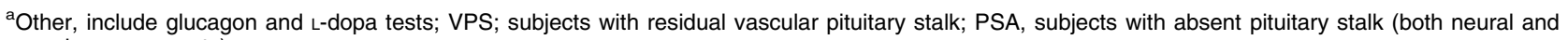
vascular components). 
Table 2 Clinical and growth hormone $(\mathrm{GH})$ response to ghrelin compared with standard pharmacological tests in adults with permanent GH deficiency and with structural hypothalamic-pituitary abnormalities.

\begin{tabular}{|c|c|c|c|c|c|c|c|}
\hline \multirow{2}{*}{$\begin{array}{l}\text { Case } \\
\text { no./sex }\end{array}$} & \multirow[b]{2}{*}{ Age } & \multirow[b]{2}{*}{ Ht (SDS) } & \multirow[b]{2}{*}{ BMI $\left(\mathrm{kg} / \mathrm{m}^{2}\right)$} & \multicolumn{2}{|c|}{ GH Peak $(\mu \mathrm{g} / \mathrm{l})$} & \multirow[b]{2}{*}{ Associated hormone deficiencies } & \multirow{2}{*}{$\begin{array}{c}\text { MRI } \\
\text { findings }\end{array}$} \\
\hline & & & & Insulin & Ghrelin & & \\
\hline $1 / F$ & 16.7 & -2.0 & 26.6 & 3.8 & 34.1 & $\mathrm{GH}+\mathrm{LH}+\mathrm{FSH}$ & VPS \\
\hline $2 / \mathrm{F}$ & 20.2 & -1.8 & 22.7 & 3.3 & 13.8 & $\mathrm{GH}$ & VPS \\
\hline 3/M & 21.3 & -0.5 & 21.7 & 0.1 & 0.5 & $\mathrm{GH}+\mathrm{TSH}+\mathrm{LH}+\mathrm{FSH}+\mathrm{ACTH}$ & PSA \\
\hline $4 / \mathrm{M}$ & 22.3 & -2.5 & 19.9 & 3.3 & 15.1 & $\mathrm{GH}+\mathrm{LH}+\mathrm{FSH}$ & VPS \\
\hline $5 / \mathrm{M}$ & 23.3 & 0.4 & 22.9 & 0.1 & 1 & $\mathrm{GH}+\mathrm{LH}+\mathrm{FSH}$ & VPS \\
\hline $6 / F$ & 23.5 & -3.78 & 18.6 & 1.2 & 0.6 & $\mathrm{GH}+\mathrm{LH}+\mathrm{FSH}+\mathrm{ACTH}$ & PSA \\
\hline 7/M & 23.6 & -2.2 & 20.8 & 0.6 & 4.6 & $\mathrm{GH}$ & VPS \\
\hline 8/M & 24.2 & -0.3 & 21.9 & 1.4 & 10.5 & $\mathrm{GH}+\mathrm{TSH}$ & VPS \\
\hline 9/F & 25.4 & -3.4 & 25.1 & 0.5 & 2.4 & $\mathrm{GH}+\mathrm{LH}+\mathrm{FSH}$ & VPS \\
\hline
\end{tabular}

VPS, subjects with residual vascular pituitary stalk; PSA, subjects with absent pituitary stalk (both neural and vascular components).

hypogonadotropic hypogonadism. Hypogonadism was confirmed in both sexes by lack of puberty or arrested puberty and no/slight/normal increase in serum FSH or LH in response to GnRH. All hormone measurements were carried out by means of standard RIAs. Ultrasonography was used to identify female patients with a prepubertal uterus.

Subjects with multiple pituitary hormone deficiencies (MPHD) were receiving conventional replacement therapy for their pituitary deficiencies: L-thyroxine 50-150 $\mu \mathrm{g} /$ day, hydrocortisone $10-20 \mathrm{mg} /$ day in two to three separate doses, testosterone enanthate 150-250 mg intramuscularly every 2 or 3 weeks for males, and ethynil estradiol (first 21 days, $5-10 \mu \mathrm{g} /$ day orally) or transdermal $17 \beta$-estradiol patches $(25-50 \mu \mathrm{g})$ with medroxyprogesterone acetate (5-10 mg, days 12-21) for females.

Sagittal and coronal T1-weighted magnetic resonance imaging (MRI), obtained using $2-3 \mathrm{~mm}$ sections, revealed structural hypothalamic-pituitary abnormalities compatible with congenital GHD, such as anterior pituitary hypoplasia, ectopic posterior pituitary gland and pituitary stalk agenesis, in all subjects. MRI with the use of contrast medium revealed the presence of a thin vascular pituitary stalk (VPS) in eight children (two with MPHD and six with isolated GHD (IGHD)) and seven adults (five with MPHD and two with IGHD), and complete pituitary stalk absence (PSA) in nine children and two adults, all with MPHD.

\section{Study design}

The clinical protocol was approved by the appropriate review boards and written informed consent for all procedures was obtained from all subjects or from their legal guardians before enrolment.

All subjects underwent ghrelin testing on separate days at least one week apart from the other tests. Ghrelin (Europeptides, Argenteuil, France) was administered at a dose of $1 \mu \mathrm{g} / \mathrm{kg}$ body weight i.v. at time zero, and blood for $\mathrm{GH}$ determination was obtained at 0 , $15,30,45,60,75,90,105$ and $120 \mathrm{~min}$.

\section{Assay}

Serum GH was assayed by chemiluminescent immunometric assay (Immulite 2000, Growth Hormone, Diagnostic Products Corporation, LA, USA). The sensitivity of the method was $0.01 \mathrm{ng} / \mathrm{ml}$. The interand intra-assay coefficients of variation were 4.2-6.6 and $2.9-4.6 \%$ respectively at $\mathrm{GH}$ levels of 2.6 and $17 \mathrm{ng} / \mathrm{ml}$ respectively. The international standard was 98/574, $1 \mu \mathrm{g} / \mathrm{l}=2.4 \mathrm{mUI} / \mathrm{l}$. All samples from each individual subject were analyzed in the same assay.

\section{Statistical analysis}

Data are non-normally distributed (Shapiro-Wilk's test) and reported as median and interquartile (IQR; $25-75^{\circ}$ percentile). The GH concentration-time curve was also expressed as median and IQR. Comparison between the two groups was performed using the Mann-Whitney $U$ test. Correlations were analyzed with Spearman's rank correlation coefficient $(\mathrm{r}) . \quad \mathrm{P}<0.05$ was considered statistically significant. All tests were two-sided. Analyses were performed with Statistica for Windows software (StatSoft, Inc., 2003, Tulsa, OK, USA).

\section{Results}

Median GH response after ghrelin was similar between children and adults (Fig. 1). Median peak GH response to ghrelin $(7.45 \mu \mathrm{g} / \mathrm{l}$, IQR: $3.9-11.3 \mu \mathrm{g} / \mathrm{l})$ was significantly higher in patients with VPS $(10.9 \mu \mathrm{g} / \mathrm{l}$, IQR: $2.4-15.1 \mu \mathrm{g} / \mathrm{l}$ ) than in those with PSA (IQR: 2.3$6.7 \mu \mathrm{g} / \mathrm{l} ; \quad P=0.001)$. It was significantly higher in subjects with IGHD $(12.5 \mu \mathrm{g} / \mathrm{l}$, IQR: $10.8-15.5 \mu \mathrm{g} / \mathrm{l})$ than in those with MPHD (5.15 $\mu \mathrm{g} / \mathrm{l}$, IQR: $2.4-9.0 \mu \mathrm{g} / \mathrm{l}$; $P=0.003 ;$ Fig. 1). No correlation was found between the GH peak after ghrelin and BMI (Spearman's $r=0.013$; $P=0.951$ ). The $\mathrm{GH}$ concentration-time curves during ghrelin testing are shown in Fig. 2. In particular, all patients showed a GH peak response to ghrelin within 30 min after ghrelin administration. 


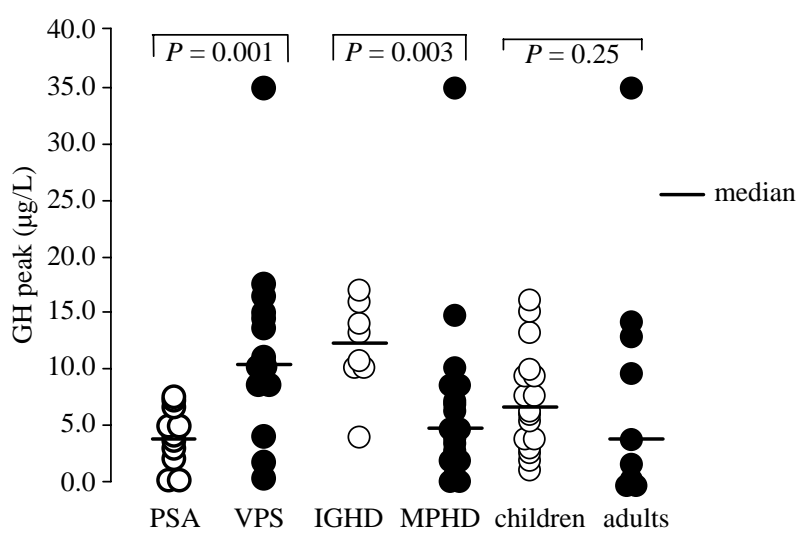

Figure 1 Median GH peak after ghrelin administration in subjects with congenital GHD. VPS, presence of a visible pituitary stalk at $\mathrm{MRI}$; PSA, absence of a visible pituitary stalk at MRI.

\section{Discussion}

Administration of ghrelin markedly stimulates $\mathrm{GH}$ secretion in animals and humans (2-6). However, in conditions under which GH secretion increases, such as exercise (16), fasting (17) and insulin-induced hypoglycemia (18), there is no parallel increase in serum ghrelin levels indicating that circulating gut-derived ghrelin is not a major regulator of pituitary GH release. Nonetheless, assessment of the effect of ghrelin in patients with GHD associated with congenital structural hypothalamicpituitary abnormalities and hypothalamic-pituitary disconnections could be helpful in elucidating the site and mechanism of action of ghrelin at the central nervous system level. In this vein, GHD patients represent a model for studying the GH effects of ghrelin in vivo. Besides, the recent identification of functional GHS receptor mutation in familial short stature discloses a potential new pathogenetic mechanism of the ghrelin-GHS-R system leading to growth failure in humans (7).

MRI has greatly improved the diagnosis of disorders of the hypothalamic-pituitary area allowing the identification of several abnormalities of the hypothalamicpituitary stalk in patients with GHD (19). Use of this imaging technique after contrast medium administration in GHD patients has permitted the identification of residual vascular components of the pituitary stalk with significantly higher accuracy than with standard MRI (20). Interestingly, a GH response to GHRH and to GHRH plus arginine has been demonstrated in the great majority of GHD patients with a residual vascular connection, as opposed to a lack of response in patients with absent pituitary stalk $(21,14)$. In other words, the $\mathrm{GH}$ responses to GHRH and to GHRH plus arginine were negatively correlated with the degree of pituitary stalk impairment as assessed by MRI. Moreover, the GH response to hexarelin, a synthetic GHS, was also detectable in patients with a residual vascular stalk and absent in patients with non-identifiable pituitary stalk $(8,11)$. Popovic et al. have also reported that both GHS analogs (9) or ghrelin (10) require the integrity of hypothalamic-pituitary connections to express their full GH-releasing activity. However, they studied adult patients with organic or surgical lesions, while we have studied children and young adults with GHD of childhood onset (mostly congenital). Furthermore, our patients were characterized on the basis of their degree of morpho-functional abnormality of the hypothalamicpituitary connections.

We have confirmed in the present study that the GH response to ghrelin requires the functional and anatomical integrity of hypothalamic-pituitary connections, but, in addition, we have demonstrated that the degree of the $\mathrm{GH}$ response to the releasing peptide might predict the degree of functional impairment of hypothalamic-pituitary connections. In fact, in both children and adults with VPS, ghrelin elicited a sizable GH response which was significantly higher than that observed in patients with PSA. These findings are similar to those observed in patients with congenital hypopituitarism after the administration of GHRH plus arginine or hexarelin $(14,11)$. As expected, all patients with PSA had MPHD, while most patients with VPS had IGHD. As a result, the GH response to ghrelin was higher in patients with IGHD than in those with MPHD,

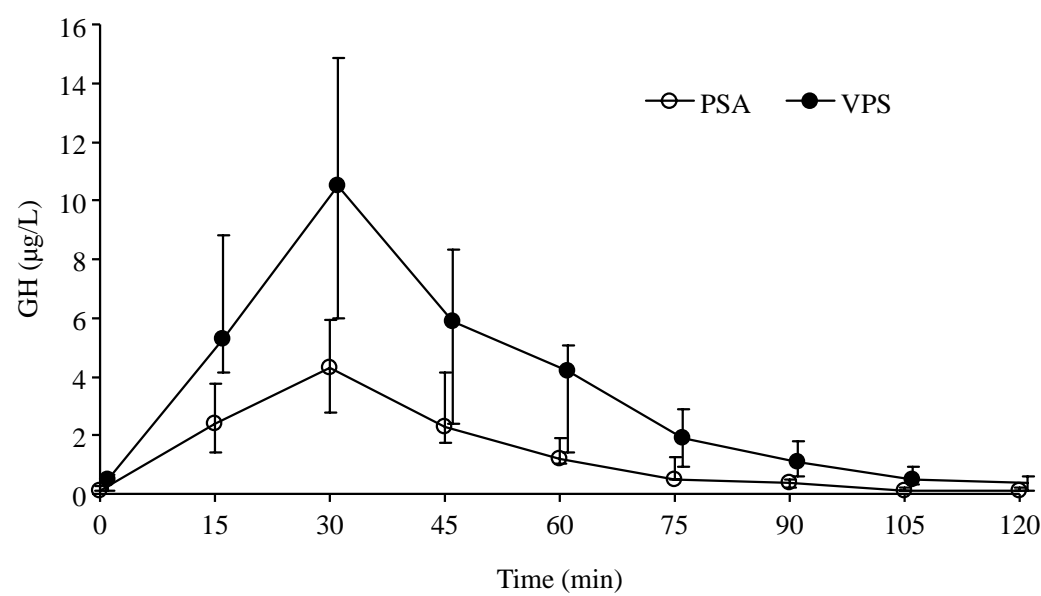

Figure 2 Median of GH secretion after ghrelin administration in children and adults with GHD associated with VPS or PSA. Bars represent $25-75^{\circ}$ percentile range. 
as previously shown after the administration of hexarelin (11). A significant GH response to ghrelin in adult patients with GHD has also been reported by Aimaretti et al. (22). However, also in this study, the patients were not characterized on the basis of the morpho-functional anatomy of their hypothalamicpituitary structures. We are aware that the absence of pituitary stalk is associated with pituitary somatotrope hypoplasia, likely as the result of a defective GHRH stimulation. Nonetheless, testing with GHRH or GHRH plus arginine has shown various degrees of GH-releasing capabilities in these patients indicating the presence of functionally preserved somatotropes $(14,21)$.

Ghrelin stimulates GH secretion in vitro and in vivo and its GH-releasing activity is mediated by the activation of the GHS receptor (23). Consistent with its GH-releasing activity, expression of the GHS receptors has been shown in the hypothalamus and the pituitary (23). However, the GH response to GHS in vivo is far more potent than that observed in vitro experiments (2-6). Abundant evidence indicates that ghrelin and the GHS require the presence of GHRH and its intact receptor to effect their full GH-releasing activity. In fact, the combined administration of GHS and GHRH stimulates a marked $\mathrm{GH}$ release which, depending on the dose, can be synergic or additive $(2-6,10)$. In the hypothalamus, ghrelin activates GHRH-containing neurons in the arcuate nucleus (24). The GH response to GHS is absent in rats and humans lacking the GHRH receptor $(24,25)$ and is also markedly reduced in animals and humans after the administration of a GHRH antagonist $(26,27)$. These observations, taken together with the finding that GHS and ghrelin necessitate the integrity of hypothalamic-pituitary connections $(8-11)$, indicate that GHSs require GHRH to effect their full GH-releasing activity. Thus, the observation that the $\mathrm{GH}$ response to ghrelin is dependent on the degree of morpho-functional abnormalities of the hypothalamic-pituitary connection would strongly support the hypothesis that hypothalamic GHRH plays a pivotal role in the GH-releasing activity of GHS.

The potential clinical implications of our findings should not be overlooked. In fact, should these findings be confirmed in larger studies comparing morphofunctional findings and responses with different secretagogs, ghrelin may be a useful additional tool in the diagnostic assessment of patients with GHD. The diagnosis of GHD is established on clinical parameters and assessment of GH secretion, IGF-I concentrations and MRI of the hypothalamic-pituitary region. GH measurement after stimulation with ITT or GHRH plus arginine provides the best diagnostic accuracy (27). Indeed, ITT is contraindicated in patients with CNS disorders and history of seizures and GHRH plus arginine can yield falsely normal responses in patients with either congenital or acquired hypothalamic-pituitary disorders (14). In these conditions, the GHS, including growth hormonereleasing peptide- 6 , hexarelin and ghrelin, may represent a reliable alternative to the classical provocative tests, provided that appropriate cutoffs are available. The fact that the $\mathrm{GH}$ response to ghrelin or its analogs is strongly influenced by the degree of the anatomical and functional impairment of hypothalamic-pituitary connections may be of particular value in characterizing the functional neuroendocrine abnormality. Moreover, it is worth pointing out that ghrelin analogs are also effective after oral administration and that their GH-releasing effect is partially resistant to the negative feedback of IGF-I (2). Therefore, the potential advantages of treatment with GHS remain an interesting matter for future studies.

In conclusion, we have shown that the administration of ghrelin stimulates $\mathrm{GH}$ secretion in patients with congenital GHD. The GH response to ghrelin in patients with congenital hypopituitarism depends on the degree of the anatomical abnormalities and lends further support to the assumption that the main action of the peptide is exerted at the hypothalamic level and requires the integrity of hypothalamic-pituitary connections.

\section{References}

1 Muller EE, Locatelli V \& Cocchi D. Neuroendocrine control of growth hormone secretion. Physiology Review 199979 511-607.

2 Van Der Lely AJ, Tschop M, Heiman ML \& Ghigo E. Biological, physiological, pathophyisiological, and pharmacological aspects of ghrelin. Endocrine Review 200425 426-457.

3 Kojima M, Hosoda H, Date Y, Nakazato M, Matsuo H \& Kangawa K. Ghrelin is a growth-hormone-releasing acylated peptide from stomach. Nature $1999 \mathbf{4 0 2} 656-660$.

4 Takaya K, Ariyasu H, Kanamoto N, Iwakura H, Yoshimoto A, Harada M, Mori K, Komatsu Y, Usui T, Shimatsu A, Ogawa Y, Hosoda K, Akamizu T, Kojima M, Kangawa K \& Nakao K. Ghrelin strongly stimulates growth hormone release in humans. Journal of Clinical Endocrinology and Metabolism $2000854908-4911$.

5 Hataya Y, Akamizu T, Takaya K, Kanamoto N, Ariyasu H, Saijo M, Moriyama K, Shimatsu A, Kojima M, Kangawa K \& Nakao KA. Low dose of ghrelin stimulates growth hormone $(\mathrm{GH})$ release synergistically with GH-releasing hormone in humans. Journal of Clinical Endocrinology and Metabolism $2000864552-4555$.

6 Arvat E, Maccario M, Di Vito L, Broglio F, Benso A, Gottero C, Papotti M, Muccioli G, Dieguez C, Casanueva FF, Deghenghi R, Camanni F \& Ghigo E. Endocrine activities of ghrelin, a natural growth hormone secretagogue (GHS), in humans: comparison and interactions with hexarelin, a non natural peptidyl GHS, and GH-releasing hormone. Journal of Clinical Endocrinology and Metabolism 200186 1169-1274.

7 Pantel J, Legendre M, Cabrol S, Hilal L, Hajaji Y, Morisset S, Nivot S, Vie-Luton MP, Grouselle D, de Kerdanet M, Kadiri A, Epelbaum J, Le Bouc Y \& Amselem S. Loss of constitutive activity of the growth hormone secretagogue receptor in familial short stature. Journal of Clinical Investigations $2006 \mathbf{1 1 6} 760-768$.

8 Loche S, Cambiaso P, Merola B, Colao A, Faedda A, Imbimbo BP, Deghenghi R, Lombardi G \& Cappa M. The effect of hexarelin on growth hormone $(\mathrm{GH})$ secretion in patients with $\mathrm{GH}$ deficiency. Journal of Clinical Endocrinology and Metabolism $1995802692-2696$.

9 Popovic V, Damjanovic S, Micic D, Djurovic M, Dieguez C \& Casanueva FF. Blocked growth hormone-releasing peptide (GHRP6)-induced GH secretion and absence of the synergic action of GHRP-6 plus GH-releasing hormone in patients with 
hypothalamopituitary disconnection: evidence that GHRP-6 main action is exerted at the hypothalamic level. Journal of Clinical Endocrinology and Metabolism $1995 \mathbf{8 0} 942-947$.

10 Popovic V, Miljic D, Micic D, Damjanovic S, Arvat E, Ghigo E, Dieguez C \& Casanueva FF. Ghrelin main action on the regulation of growth hormone release is exerted at hypothalamic level. Journal of Clinical Endocrinology and Metabolism $2003 \mathbf{8 8}$ 3450-3453.

11 Maghnie M, Spica-Russotto V, Cappa M, Autelli M, Tinelli C, Civolani P, Deghenghi R, Severi F \& Loche S. The growth hormone response to hexarelin in patients with different hypothalamicpituitary abnormalities. Journal of Clinical Endocrinology and Metabolism $1998 \mathbf{8 3} 3886-3889$.

12 Ghigo E, Bellone J, Amaretti G, Bellone S, Loche S, Cappa M, Bartolotta E, Dammacco F \& Capanni F. Reliability of provocative tests to assess growth hormone secretory status, study in 472 normally growing children. Journal of Clinical Endocrinology and Metabolism 199681 3323-3327.

13 Ghigo E, Aimaretti G, Gianotti L, Bellone J, Arvat E \& Camanni F. New approach to the diagnosis of growth hormone deficiency in adults. European Journal of Endocrinology $1996134352-356$.

14 Maghnie M, Salati B, Bianchi S, Rallo M, Tinelli C, Autelli M, Aimaretti G \& Ghigo E. Relationship between the morphological evaluation of the pituitary and growth hormone $(\mathrm{GH})$ response to GH-releasing hormone plus arginine in children and adults with congenital hypopituitarism. Journal of Clinical Endocrinology and Metabolism 200186 1574-1579.

15 Maghnie M, Aimaretti G, Bellone S, Bona G, Bellone J, Baldelli R, de Sanctis C, Gargantini L, Gastaldi R, Ghizzoni L, Secco A, Tinelli C \& Ghigo E. Diagnosis of GH deficiency in the transition period: accuracy of insulin tolerance test and insulin-like growth factor-I measurement. European Journal of Endocrinology 2005152 589-596.

16 Dall R, Kanaley J, Hansen TK, Moller N, Christiansen JS, Hosoda H, Kangawa K \& Jorgensen JO. Plasma ghrelin levels during exercise in healthy subjects and in growth hormone-deficient patients. European Journal of Endocrinology 2002 147 65-70.

17 Espelund U, Hansen TK, Hojlund K, Beck-Nielsen H, Clausen JT, Hansen BS, Orskov H, Jorgensen JO \& Frystyk J. Fasting unmasks a strong inverse association between ghrelin and cortisol in serum: studies in obese and normal-weight subjects. Journal of Clinical Endocrinology and Metabolism 200590 741-746.

18 Lucidi P, Murdolo G, Di Loreto C, De Cicco A, Parlanti N, Fanelli C, Santeusanio F, Bolli GB \& De Feo P. Ghrelin is not necessary for adequate hormonal counterregulation of insulin-induced hypoglycemia. Diabetes $2002512911-2914$.

19 Maghnie M, Genovese E, Villa A, Spagnolo L, Campani R \& Severi F. Dynamic MRI, in the congenital agenesis of the neural pituitary stalk syndrome: the role of the vascular pituitary stalk in predicting residual anterior pituitary function. Clinical Endocrinology $1996 \mathbf{4 5} 281-290$.

20 Maghnie M, Genovese E, Arico M, Villa A, Beluffi G, Campani R \& Severi F. Evolving pituitary hormone deficiency is associated with pituitary vasculopaty: dynamic MR study in children with hypopituitarism, diabetes insipidus, and Langherans cell histiocyosis. Radiology 1994193 493-499.

21 Maghnie M, Moretta A, Valtorta A, Larizza D, Sayegh M, Greco AM, Castoldi E \& Severi F. Growth hormone response to growth hormone-releasing hormone varies with the hypothalamic pituitary abnormalities. European Journal of Endocrinology $1996135198-204$.

22 Aimaretti G, Baffoni C, Broglio F, Janssen JA, Corneli G, Deghenghi R, van der Lely AJ, Ghigo E \& Arvat E. Endocrine responses to ghrelin in adult patients with isolated childhoodonset growth hormone deficiency. Clinical Endocrinology $2002 \mathbf{5 6}$ 765-771.

23 Howard AD, Feighner SD, Cully DF, Arena JP, Liberator PA, Rosenblum CI, Hamelin M, Hreniuk DL, Palyha OC, Anderson J, Paress PS, Diaz C, Chou M, Liu KK, McKee KK, Pong SS, Chaung LY, Elbrecht A, Dashkevicz M, Heavens R, Rigby M, Sirinathsinghji DJ, Dean DC, Melillo DG, Patchett AA, Nargund R, Griffin PR, De Martino JA, Gupta SK, Schaeffer JM, Smith RG \& Van der Ploeg LH. A receptor in pituitary and hypothalamus that functions in growth hormone release. Science $1996 \mathbf{2 7 3} 974-977$.

24 Dickson SL, Doutrelant-Viltart O \& Leng G. GH-deficient $\mathrm{dw} / \mathrm{dw}$ rats and lit/lit mice show increased Fos expression in the hypothalamic arcuate nucleus following systemic injection of GH-releasing peptide-6. Journal of Endocrinology 1995146 519-526.

25 Maheshvari HG, Rahim A, Shalet SM \& Baumann G. Selective lack of growth hormone $(\mathrm{GH})$ response to the GH-releasing peptide hexarelin in patients with GH-releasing hormone receptor deficiency. Journal of Clinical Endocrinology and Metabolism 1999 84 956-959.

26 Bowers CY, Sartor AO, Reynolds GA \& Badger TM. On the actions of the growth hormone-releasing hexapeptide, GHRP. Endocrinology $19911282027-2035$.

27 Pandya N, DeMott-Friberg R, Bowers CY, Barkan AL \& Jaffe CA. Growth hormone $(\mathrm{GH})$-releasing peptide- 6 requires endogenous hypothalamic GH-releasing hormone for maximal GH stimulation. Journal of Clinical Endocrinology and Metabolism $1998 \mathbf{8 3}$ 1186-1189.

Received 25 October 2006

Accepted 23 January 2007 